\title{
Feelings and Perceptions of Women in the Pregnancy-Puerperal Cycle Who Survived Severe Maternal Morbidity
}

\author{
Ana Paula Pinho Carvalheira ${ }^{1}$ \\ Vera Lúcia Pamplona Tonete ${ }^{2}$ \\ Cristina Maria Garcia de Lima Parada ${ }^{3}$
}

\begin{abstract}
This study aimed to understand severe maternal morbidity from the perspective of women who experienced it. The methodological precepts of qualitative research were adopted and the Collective Subject Discourse was the methodological framework chosen. A total of 16 women who experienced severe maternal morbidity were interviewed. Results were discussed based on four themes: describing the desire and plan for having a child; acknowledging the health problem and its influence on pregnancy and on the conceptus; overcoming the initial shock postpartum, and experiencing the risk situation: desires, frustration, and overcoming. This study will contribute to qualifying nursing care, specifically acknowledging the diversity and breadth of the needs presented by women in situations of severe morbidity during the pregnancy-puerperal cycle.
\end{abstract}

Descriptors: Morbidity; Pregnancy, High-Risk; Qualitative Research; Nursing.

\footnotetext{
${ }^{1}$ RN, Master's Student, Faculdade de Medicina de Botucatu, Universidade Estadual Paulista "Júlio de Mesquita Filho", SP, Brazil. E-mail: nana_carvalheira@hotmail.com.

${ }^{2}$ RN, Ph.D. in Nursing, Assistant Professor, Faculdade de Medicina de Botucatu, Universidade Estadual Paulista "Júlio de Mesquita Filho", SP, Brazil. E-mail: vtonete@uol.com.br.

${ }^{3}$ RN, Free Lecture, Adjunct Professor, Faculdade de Medicina de Botucatu, Universidade Estadual Paulista "Júlio de Mesquita Filho", SP, Brazil. E-mail: cparada@fmb.unesp.br.
}

Corresponding Author:

Cristina Maria Garcia de Lima Parada

UNESP. Faculdade de Medicina de Botucatu. Departamento de Enfermagem

Campus Universitário Rubião Júnior, $\mathrm{s} / \mathrm{n}$.

CEP 18618-970, Botucatu, SP, Brasil.

E-mail: cparada@fmb.unesp.br 


\title{
Sentimentos e percepções de mulheres no ciclo gravídico puerperal que sobreviveram à morbidade materna grave
}

Objetivou-se compreender a experiência relativa à morbidade materna grave, a partir de um grupo de mulheres que vivenciou esse problema. Adotaram-se os preceitos metodológicos da pesquisa qualitativa, sendo o Discurso do Sujeito Coletivo o referencial metodológico. Foram entrevistadas 16 mulheres que vivenciaram a morbidade materna grave. Os resultados foram discutidos a partir de quatro temas: descrevendo o desejo e o planejamento para ter um filho, percebendo seu problema de saúde, sua influência na gestação e para o concepto, passando pelo choque inicial no pós-parto e experienciando a situação de risco: desejos, frustrações e superação. Espera-se que este trabalho possa contribuir para qualificar a assistência de enfermagem, especialmente para reconhecer a diversidade e amplitude de necessidades que mulheres apresentam em situações de morbidade grave, durante o ciclo gravídico puerperal.

Descritores: Morbidade; Gravidez de Alto Risco; Pesquisa Qualitativa; Enfermagem.

\section{Sentimientos y percepciones de mujeres en el ciclo embarazo-puerperio que sobrevivieron a una morbosidad materna grave}

\begin{abstract}
Se tuvo por objetivo comprender la experiencia relativa a morbosidad materna grave, a partir de un grupo de mujeres que experimentó ese problema. Se adoptaron los preceptos metodológicos de la investigación cualitativa, siendo el Discurso del Sujeto Colectivo el referencial metodológico. Fueron entrevistadas 16 mujeres que experimentaron morbosidad materna grave. Los resultados fueron discutidos a partir de cuatro temas: describiendo el deseo y la planificación para tener un hijo; percibiendo su problema de salud, su influencia en la gestación y en el concepto; pasando por el choque inicial del post-parto; y, experimentando la situación de riesgo: deseos, frustraciones y superación. Se espera que este trabajo pueda contribuir para calificar la asistencia de enfermería, especialmente reconocer la diversidad y amplitud de las necesidades que las mujeres presentan en situaciones de morbosidad grave durante el ciclo de embarazo y puerperio.
\end{abstract}

Descriptores: Morbilidad; Embarazo de Alto Riesgo; Investigación Cualitativa; Enfermería.

\section{Introduction}

Prenatal care represents an opportunity to provide guidance concerning aspects inherent to the physiological process of pregnancy and promoting health, in addition to performing prophylaxis, diagnosis and treating diseases inherent to the pregnancy itself or intercurrent ${ }^{(1)}$, in order to achieve its ultimate goal: reduced maternal and perinatal morbidity and mortality.

The analysis of maternal deaths demonstrates the variations not only among countries but also in different regions of the same country or even state. The World Health Organization (WHO) estimates that 20 million women in the world currently experience acute complications during pregnancy, with the occurrence of 529,000 deaths $^{(2)}$.

Maternal death is an underestimated problem in Brazil. Approximately 76 maternal deaths to every 100,000 live births were estimated for $2002^{(3)}$. Because these deaths are spread out over the Brazilian territory, one gets the impression they are rare when the number of deaths by institution, even referral services, are taken into account. This perception impedes the acknowledgement of maternal death as a public health problem and hinders the investigation of its determinants. 
However, not only is maternal death relevant, but also morbidity that includes different levels of severity and indicates the need to better understand the problems related to pregnancy, delivery and puerpuerium, which do not necessarily result in death but cause suffering and sequelae in women(4). From this perspective, the interest in case studies addressing severe morbidity during the pregnancy-puerperal cycle has increased, particularly in extremely severe cases characterized by near miss, since they present potentially fatal complications in women, who survive due to luck or good hospital care(5).

Acknowledging the importance of listening in the development of integral and humanized care, this study was proposed to understand severe maternal morbidity from the perspective of a group of women who experienced it.

\section{Method}

This qualitative study addresses the meanings attributed to severe maternal morbidity. The notion of meaning, largely used in qualitative research, has a structuring function: people organize their lives based on the meaning they attribute to things, including selfcare. Hence, the idea of meaning assumes there is an interaction between thought and experience, anchored in a theoretical framework, which if treated common sensically, loses the richness of their potential to explain reality ${ }^{(6)}$.

The Collective Subjective Discourse (CSD) was the theoretical reference chosen. It is a way to systematize verbal qualitative data obtained from social groups, based on key expressions grouped around central or similar ideas, composing one or various reports-synthesis in the first-person singular(7).

The study was carried out in Botucatu, a town with about 120,000 inhabitants, located in the southcentral region of the state of São Paulo, Brazil, in a tertiary referral service that cares for an average of 100 pregnant women per month.

A total of 16 women participated in this study. They were included based on their condition of morbidity, regardless of whether their pregnancy ended in birth or miscarriage or whether they were still pregnant or had already given birth. The number of participants was defined based on theoretical saturation, that is, no new participants were included in the study when data began to be redundant or repeated according to the researcher's opinion.
One of the authors was responsible for inviting the potential participants, then collecting and recording data through semi-structured interviews. Interviews were carried out at the hospital after discharge, by which time potential transitory sequelae in terms of communication were supposedly overcome and also a point when women were more physically stable. Interviews were individually carried out in a light and airy room, especially organized for this purpose, and were initiated with the following: "Please respond to the following questions considering your experience with a severe maternal disease. Was the pregnancy planned? How was it to have experienced a severe disease and survived?"

This study was submitted to and approved by the local Research Ethics Committee linked to the National Research Ethics Committee and complied with all the requirements for research performed with human subjects (Of. n²94/08-CEP).

\section{Results and Discussion}

A brief characterization of the interviews indicates that the reasons these women were referred for high-risk prenatal follow-up or were hospitalized in tertiary service were diverse, however, there was a predominance of preeclampsia in 13 (81.3\%) women followed by one case of hemorrhage and another of uterine rupture that resulted in hysterectomy, and one case of miscarriage.

The qualitative analysis of interviews enabled us to systematize 10 CSD in four themes. These are presented with their respective central ideas and identification of interviewees who contributed to the reports.

\section{Theme 1 - Describing the desire and plan for having a child}

The process of entering motherhood begins long before conception, from a woman's earliest relationships and identifications, passing through children's play, adolescence, to the desire to have a child and pregnancy per se. Cross-generational and cultural aspects also contribute to this process, associated with what is expected from a girl and woman, both within the family and society ${ }^{(8)}$

The decision to have a child is the result of various conscious and unconscious motives, including the desire to deepen the woman-man relationship, the desire to concretize continuity and immortality, of recovering a broken bond, of competing with relatives, or even of filling an inner emptiness, among others ${ }^{(9)}$. 
The following report evidenced these issues:

CSD 1 - It wasn't planned (pregnancy)... I had no intention to get pregnant, but I'm not saying it wasn't welcome, on the contrary, it was well loved. I endured two miscarriages before this pregnancy, both miscarriages occurred before the second month, I still don't know why... So, I gave up on having children. I mean, not on having children, I gave up getting pregnant, but not of having children because I was considering an adoption and when I was about to apply for adoption, I found out I was pregnant and it was really good, a gift. It has been a blessing so far, despite all the difficulties (Central Idea A - I did not plan, but it has been a blessing. Interviews 1-3, 7-15).

Women reported they had not planned the pregnancy but acknowledged that despite all the difficulties, they loved their children. In summary, they view the unplanned pregnancy as a blessing. As the pregnancy advances, the woman becomes accustomed to the situation of risk and feels more confident and believes that the problems accruing from the situation are compensated by the opportunity of becoming a mother.

Unplanned pregnancies are frequent among women of different ages and schooling levels, however, the fact the pregnancy was not planned does not necessarily mean the child is not wanted(10). It is known that an initial rejection may give place to acceptance, though the opposite may also occur( ${ }^{(9)}$.

Experiencing a risk pregnancy emerges from CSD 2:

CSD 2 - I didn't plan it, I was taking medication and all, but then I got pregnant... I was aware that I was facing the risk of death. The physicians had already told me, because I had two previous pregnancies with eclampsia and preeclampsia. So, this time, I could face a high-risk pregnancy, could lose either my life or the baby, or even lose both, or even save both (Central Idea B - I had already endured a high risk pregnancy, that is why I did not planned this one. Interviews 9 and 11).

Aware of the problems and potential consequences a high-risk pregnancy can trigger, the puerperal women represented pregnancy as an event that put their lives and/or those of their children at risk.

Fear, anxiety and expectations originate in the women's previous experiences and information received. Hence, when entering into motherhood, women have a preconceived idea of how the delivery will occur, of how they will be cared for and what difficulties they will have to face ${ }^{(11)}$.

Women have the right to be informed about their experiences, especially when becoming pregnant and mothers, the right to know their own body, to live to raise their children and learn their maternal duties.
This right is not restricted to the pregnancy-puerperal cycle and should be complied with in all phases of life, especially when there are pathologies interfering.

Women expressed fear of death, not only of themselves but also for their children. A maternal death is an event that occurs when life is being generated, which makes it even more inconceivable given the profound marks it leaves on families and professionals ${ }^{(12)}$.

In contrast to the other reports recorded so far, CSD 3 refers to planned pregnancies:

CSD 3 - It was planned (pregnancy). It has been three years since we got married and we have very much wanted a child, only that I couldn't get pregnant; we both had to undergo treatment. When we learned about it, we jumped for joy, couldn't wait for it, she's a very loved child (Central Idea C - I have planned my pregnancy. Interviews 4-6)

Even when a family prepares itself to receive a child, it manifests feelings of joy and fear, hope and insecurity, illusion and uncertainty, acceptance and disapproval, involved in projects of personal and family realizations $^{(9)}$. This report is anchored in the view that a child complements a marriage.

\section{Theme 2-Acknowledging the health problem and its influence on pregnancy and on the conceptus}

Knowledge related to the health problem that classified the woman as having a severe maternal morbidity is discussed below with CSD 4 and CSD 5, in which the importance of religion is also expressed by interviewees.

CSD 4 - Look! I feel very well; thank God, I'm here! From what the physician explained to me, everything was done trying to stop the bleeding, but there was no improvement. The last alternative would be it, it had to be done, you know? (hysterectomy). I thank God for being here after everything that happened... I got here in such a situation, I really felt I was at risk of death, but thank God I overcome everything and when I got here, I looked through the window and realized how good it is to be alive, very good! I'm really well (Central Idea A - I realized that I was at risk of death, but I am well now. Interviews 1-2).

Once more pregnancy was represented as risk of death. However, after all the concerns and anxiety experienced by the interviewed women, their reports expressed relief for having the situation under control, the joy of being alive, and the important role of religious beliefs in overcoming problems.

CSD 4 reveals that the respondents conformed to the situation, they understood and accepted the hysterectomies that they underwent. They anchored their reports in religion, attributing to God the grace of having 
overcome their health problem. Health professionals need to know what is important in comforting their patients, and also acknowledge their religious needs. On the other hand, they also need to do everything possible to relieve their suffering and keep the hope alive for those for whom they care. Aspects related to religious faith also emerge in CSD 5.

CSD 5 - It wasn't easy for me but thank God I'll get better every day. If I'm holding on it's because of them, they give me great strength in this church, they pray, you go in crying and leave laughing. So, that's it, but it's a difficulty, the only thing I can say is that if I go there everyday, it's because I find myself in the church (Central Idea B - I find strength in my church. Interviews 1-2, 5, 13 and 15)

This report reveals that religious faith results in hope and strengthening, enabling one to go on, to fight and cope with difficulties. Often, the appeal to restore health through religion occurs not only in relation to health problems, but in various dimensions of human life that are not dissociated from health such as psychological, social, and cultural aspects, among others. The religious universe exists and is meaningful in the lives of individuals and is an important resource used in the search for answers to health problems, for treating situations faced in life and even in situations with likely fatal results(13).

According to the constructionist concept of risk, the human being has the ability and opportunity to come and make choices: suffer or learn to deal with situations, taking a lesson from them(14). It is noteworthy, however, that when one overlaps belief and knowledge, one may not value the origin of the pathology and give to God the credit for having the strength necessary to overcome the challenge of the illness, pregnancy and the condition of being a mother(15).

Guilt-feelings, due to the possibility of losing the child, were identified in CSD 6:

CSD 6 - For me it was a situation, like, I don't know how to explain, it was the most horrible thing in the world, a torture. So far, there's been nothing worse than this. I believe that not even my two miscarriages were as difficult as this, because it happened suddenly, but think about someone saying: I need to do it because your daughter can die now, at any moment, it was a feeling like: I'm killing my daughter. It was how I felt at that moment. I keep thinking what did I do wrong? What happened? I keep remembering my entire pregnancy... there's no way! I feel guilty. I try to find the mistake I made during my pregnancy... Why is my body rejecting my child? (Central Idea C - It was horrible, I felt I was killing my daughter, I felt guilty. Interviews 3-15).
CSD 6 reveals that pregnancy was represented as a possibility of losing the baby. Virtually all the interviewees contributed to this report and the great concern of these women in relation to their children's lives became clear. Having a healthy child is what matters most for them.

Feelings of guilt and of having committed some wrong deed can complicate the evolution of a highrisk pregnancy. Maternal guilt can also be perceived in CSD 6. A severe maternal morbidity is represented as something associated with the mother's mistakes during the pregnancy that supposedly resulted in her body's rejecting the child, generating guilt. In this case, the report is anchored in the pregnancy's biological aspects and in the morbidity, especially addressing the repercussions of the placental malfunction on the fetus.

The feeling of guilt stems from a law under which people are governed, people who accepted its symbolic dimension, actual guilt that affects us given our faults and daily acts. More specifically, guilt is characterized by the fact that these moral rules were internalized by the individual, therefore, guilt is different from fear of external punishment ${ }^{(16)}$.

The need to anticipate the birth due to the mother's body rejecting the fetus, is also reported. A study on the relationship between parents and premature babies indicated that usually the mother reports feelings of guilt for wanting to have a perfect, healthy, and full term child and be able to have the child at home right after his/her birth(17).

The birth of a preterm baby characterizes a moment of crisis for the family. Given the child's risk of death, feelings of guilt, anxiety, concern, and confusion emerged in the parents. Coupled with this is the fact that the mother does not develop early bonding and breastfeeding. After birth, being in need of immediate support, the newborn is usually referred to the neonatal unit. The sudden removal of the child from the mother, prolonged during hospitalization, associated with the infant's fragile condition, is responsible for feelings of loss and early mourning(18).

\section{Theme 3 - Overcoming the initial shock postpartum}

There is not, in the family cycle, any stage that causes a change more profound or that poses a higher challenge than the arrival of a child. In the case of the birth of a newborn at risk, whether a premature or sick child, the family sees itself in the face of a stressful and challenging experience, which results in deep changes in the family dynamics, and is prolonged with the child's hospitalization(19). 
CSD 7 - When she passed by me I saw her little arm and heard a squeak, then she cried and I heard nothing else. Then, in the morning I asked about her and she had been sent to the ICU. I'm not blaming anyone, but it was 2:30pm and I had no news about my daughter. I said: I need to know about my daughter! Then the physician explained to me that many children were born and she had no time to come and tell what was happening, but she was fine...that I should be patient until I'd be able to get up, that I could see her any time... (Central Idea A - I had no news about my child after birth. Interviews $3,5-6,8)$

CSD 7 reveals the fact that the child was not in a condition to be kept with her mother right after the birth, given the high-risk pregnancy. The mothers express, here, that care was inadequate due to the lack of information concerning the child. Information is, however, an important component of care and nursing practice, an inalienable right of individuals and a factor capable of improving morbidity ${ }^{(20)}$. The justification given for the lack of information is readily accepted by the mother who based her report on the technical-scientific discourse provided to explain the difficulties faced due to excessive work. Again, the child's biological aspects are pointed out, which explain her well being, despite the need to be hospitalized in the ICU.

It is necessary to know how the interaction between mother and the multi-professional team occurs, how the health services difficulties are coped with daily, in the search of achieving the goal of developing a quality health care. This is not an easy task, added to the fact there is limited literature addressing the theme of communication between the members of the health team and women in the puerperal-pregnancy cycle and to the limited number of places where care is delivered by an integrated multi-professional team(21). Communication from this perspective is a therapeutic resource that gives access to autonomy, mutual trust and security, enabling interactions between the health team and the family. As a challenge in the search of quality care, this tool orients the interventions and consolidates the conception of providing health in the hospital context ${ }^{(22)}$.

Suffering from having a child with a severe health condition is evident in CSD 8.

CSD 8 - It's really difficult, terrible, and difficult to talk about. We dream about a child, to get him in our lap, breastfeed, and today is his sixth day of life and I haven't been with him yet.
He is being fed through a catheter, so it's a difficult situation, you know? So, it messes a little with you psychologically, I've cried a lot already. Today, I'm fine, yesterday and today I'm better, but I've suffered a lot. Whenever I saw him, I'd cry all the time, look at him with the paraphernalia, you can tell he's suffering, so little and already suffering like this... It's shocking, I wish I were in his place so he'd be well. The pain, wow, the pain of thinking of him there, having to go and leaving him... But I have to thank God for that, for Him having given me the opportunity to experience this, which is painful but I guess it will serve in the future (Central Idea B - It was painful seeing my child in the ICU, we dream about having our child in our lap, breastfeed...Interviews 3-4, 6-7, 10-11,15).

Facing the unexpected is a great challenge for these women. A high-risk pregnancy is represented as something that leads to the birth of a child that demands much care, thus causing suffering, but also as something that brings experience to the lives of these women and enabled them to experience motherhood.

The puerperal period was identified and described by these women as a difficult period due to emotional instability, which is more than justified by the newborn's severe condition. Increased sensitivity, unstable moods such as nervousness and crying are common during pregnancy, birth and puerperium, explained by changes in metabolism. Even women who accept pregnancy can either laugh or cry, and manifest irritation and vulnerability to external stimuli that would not affect them otherwise ${ }^{(9)}$.

The absence of interventions directed to the accompanying mother, listening and supporting activities, during the difficult process of having a child hospitalized in a hospital unit of high complexity does not meet the needs of women included in a real family. In general, the focus of care in maternal-child services is centered on biological aspects of breastfeeding, giving priority to the single function of producing milk to nurture the child. This approach needs to be reviewed to enlarge the object of action beyond the anatomophysiological body, so that women are not solely seen as a being isolated from their social context(23).

\section{Theme 4 - Experiencing the risk situation: desires, frustrations and overcoming}

Given the theme, all women described the experience as a difficult period, of much suffering and fear of losing the child. They had difficulty looking at themselves. 
The woman expects and awaits the outcome of the pregnancy and hospitalization of her child, an almost always agonizing wait, based on assumptions, probabilities, promises and hopes. Women experience constant tension in this phase, feel vulnerable and even though they tend to wait for what they desire, they fear the unexpected as CSD 9 shows.

CSD 9 - It was a painful experience, you know, like her birth itself. I had agreed with my father that it was going to be recorded, filmed. I wanted to have a normal delivery because it is much easier, it's natural and I've always liked things to happen naturally... So, it was exactly the opposite of everything I dreamed of. This was also a complicated situation and I don't know if anyone will ever understand it, but think about a person going to a medical consultation and leaving the hospital with the baby in the ICU... It was a very painful experience (Central Idea A - It was a painful experience. Interviews 3 and 6).

The experience was represented as painful because it resulted in the birth of a child with a severe health condition, preventing those previously idealized actions of receiving the baby to become true. Other fears of motherhood were frequently expressed in dreams and fantasies. Hence, it is very common to dream about the delivery, body changes and the baby, expressing expectations in relation to the baby ${ }^{(9)}$.

It is also worth mentioning that the choice of the type of birth leads to great clinical discussion but in general the pregnant woman does not participate in this discussion and is only informed about the medical decision. The woman is led to think and act according to the convenience of the current system and receives information all the time about the risks involved in pregnancy and delivery, which consequently lead them to fear $^{(24)}$.

Overcoming all the problems emerge in CSD 10.

CSD 10 - We want to take the baby home because he is our child... Now I'm calmer, I know he's being cared for, is well, he gained some weight, even fasting he gained weight, so he's getting better, and soon he'll be in my arms... (Central Idea B He will be soon in my arms. Interviews 3-4, 6-7, 10-11, 15).

In CSD 10, once more, the focus is on the child. Severe maternal morbidity is represented as something that may end well. This report is anchored in the view that appropriate care leads to the newborn's improvement and his/her consequent inclusion in the family environment.

\section{Final considerations}

The qualitative approach used in this study was appropriate for the addressed theme and enabled achieving the proposed objective, understanding severe maternal morbidity from the perspective of women who experienced it.

Great expectation was observed in women in relation to the future of their lives and that of their children, both during pregnancy and after birth. They were apprehensive, feared death, the unexpected and losing their children. However, they expected to have success at the end of the process through which they were going. The desire to resume their healthy lives was evident and they often anchored themselves in religious beliefs, because they believed God would give them the strength necessary to overcome the challenge of the disease, the pregnancy and the condition of being mothers. Therefore, it is also important that the planning of health care includes this issue as a strategy to increase women's disposition to overcome difficulties.

Another important aspect to consider in women's care during the pregnancy-puerperal cycle is the quality of information and care provided for both the physical and emotional aspects and that should be ensured to the mothers and children. The perception of risk of death brings many feelings with different intensities. Feelings such as fear, anxiety and guilt, can be ameliorated. Appropriate interaction among the multi-professional team, mother and child should be valued. Welcoming these mothers should be a priority from the moment of admitting the newborn, including them as participants in the child's recovery in a positive manner, respecting their expectations and individuality. Considering maternal needs, health professionals in general, and nurses in particular, can improve the process of care delivered to these women and their children, providing more security and valuing self-esteem and mutual trust.

This study is expected to contribute to qualify nursing care, especially related to the need to acknowledge the diversity and breadth of needs women have in situations of severe morbidity, seeking an integral and non-generalized care, health promotion and the prevention of harm to both mother and child. 


\section{References}

1. Presidência da República (BR). Secretaria Especial de Política para as Mulheres. Plano Nacional de Política para as Mulheres. Brasília (DF): Ministério da Saúde; 2004. 101 p.

2. World Health Organization. Maternal mortality in 2000: estimates developed by WHO, UNICEF, and UNFPA. Geneva: World Health Organization; 2003. 39 p.

3. Ministério da Saúde (BR). Departamento de Informática do SUS. Indicadores e dados básicos: Brasília; 2004. [acesso: 17 mar 2008]. Disponível em: http://tabnet.datasus.gov.br/cgi/ idb2004/folder.htm

4. Aquino E. Repensando a mortalidade nos marcos dos direitos reprodutivos de jovens e adolescentes. Perspect Saúde Direitos Reprod. 2002;3(5):14-8.

5. Pattinson RC, Hall M. Near misses: a useful adjunct to maternal death enquiries. Br Med Bull. 2003;67(1):231-43.

6. Turato ER. Métodos qualitativos e quantitativos na área da saúde: definições, diferenças e seus objetos de pesquisa. Rev Saúde Pública. 2005; 39(3):507-14.

7. Lefèvre $F$, Lefèvre $A M C$, organizadores. $O$ discurso do sujeito coletivo: um novo enfoque em pesquisa qualitativa (Desdobramentos). 2. ed. Caxias do Sul: Educs; 2005. 260 p.

8. Aragão R. De mãe para filha: a transmissão da maternidade. In: Melgaço R, organizador. A ética na atenção ao bebê: psicanálise, saúde e educação. São Paulo (SP): Casa do Psicólogo; 2006. $226 \mathrm{p}$.

9. Maldonado MT. Psicologia da gravidez: parto e puerpério. 16 ed. São Paulo (SP): Saraiva; 2002. 229 p.

10. Silva L, Santos RC, Parada CMGL. Compreendendo o significado da gestação para grávidas diabéticas. Rev. LatinoAm. Enfermagem. 2004;12(6):899-904.

11. Oliveira ME, Zampieri MFM, Brüggemam OM. A melodia da humanização: reflexões sobre o cuidado no processo do nascimento. Florianópolis (SC): Cidade Futura; 2001. 131 p.

12. Assis ILR. Gravidez de alto risco: a percepção das gestantes [dissertação de mestrado]. Belo Horizonte (MG): Departamento de Enfermagem da Universidade Federal de Minas Gerais; 2004. 90 p.
13. Fleck MPA, Borges ZN, BolognesiG, Rocha NS. Desenvolvimento do WHOQOL, módulo espiritualidade, religiosidade e crenças pessoais. Rev Saúde Pública. 2003; 37(4):446-55.

14. Martins J, Bicudo MAV. A pesquisa qualitativa em psicologia: fundamentos e recursos básicos. São Paulo (SP): Centauro; 2003. $110 \mathrm{p}$.

15. Vieira RJS. Câncer de mama e gravidez subseqüente: um olhar sociocultural [tese de doutorado]. Rio de Janeiro (RJ): Instituto Fernandes Figueira; 2004. 108 p.

16. Peres UT. Culpa. In: Peres UT. Por que a culpa? São Paulo (SP): Escuta; 2001. p. 7-14.

17. Martinez JG. Neonato prematuro em riesgo de deterioro de vínculo padres-hijo: coping. Dessarollo Enferm. 2006;14(3):99-104.

18. Silva GRG. O ambiente frio e cuidado morno: a enfermagem possibilitando a aproximação entre pais e filhos na UTI neonatal [dissertação de mestrado]. Rio de Janeiro(RJ): Faculdade de Enfermagem da Universidade do Rio de Janeiro; 2000. 97 p.

19. Baldiniv SM, Krebs VLJ. Reações psicológicas nos pais de recém-nascidos internados em unidade de terapia intensiva. Pediatr Mod. 2000;36 (Supl 1):242-6.

20. Martins JCA. Satisfação do doente com a informação sobre a doença e morbidade. Rev. Latino-Am. Enfermagem. 2009;17(3):335-40.

21. Silva VW. A comunicação interpessoal entre os profissionais de saúde e gestantes na assistência pré-natal. São Paulo (SP): Manole; 2002. 106 p.

22. Bittes A Jr, Matheus MCC. Comunicação. In: Cianciarullo TI. Instrumentos básicos para o cuidar: um desafio para a qualidade de assistência. São Paulo (SP): Atheneu; 2000. p. 61-73.

23. Javorsky M, Caetano LC, Vasconcelos MGL, Leite AM, Scochi CGS. As representações sociais do aleitamento materno para mães de prematuros em unidade de cuidado canguru. Rev. Latino-Am. Enfermagem. 2004;12(6):890-8.

24. Tedesco RP, Maia NL Filho, Mathias L, Benez AL, Castro VCL, Bourroul GM, et al. Fatores determinantes para as expectativas de primigestas acerca da via de parto. Rev Bras Ginecol Obstet. 2004;26(10):791-8.

Received: Dec. 16 th 2009

Accepted: Ago. $4^{\text {th }} 2010$ 